\title{
Evaluation of the viability of recycling railroad ballast for reusing in railroads
}

\author{
Avaliação da viabilidade de reciclagem de lastro ferroviário para reutilização em ferrovia \\ Evaluación de la viabilidad del reciclaje de balasto ferroviario para su reutilización en vías férreas
}

Received: 09/29/2021 | Reviewed: 10/04/2021 | Accept: 11/09/2021| Published: 10/12/2021

\author{
Jhenifer Terezinha Aparecida Mattos Cescon \\ ORCID: https://orcid.org/0000-0002-5234-2905 \\ Military Institute of Engineering, Brazil \\ E-mail: jhenicescon@gmail.com \\ Ben-Hur de Albuquerque e Silva \\ ORCID: https://orcid.org/0000-0001-6933-498X \\ Military Institute of Engineering, Brazil \\ E-mail: benhur@ime.eb.br \\ Maria Esther Soares Marques \\ ORCID: https://orcid.org/0000-0001-8936-2777 \\ Military Institute of Engineering, Brazil \\ E-mail: esther@ime.eb.br \\ Romero Pereira dos Santos \\ ORCID: https://orcid.org/0000-0001-5220-1451 \\ MRS Logistics, Brasil \\ E-mail: romero.santos@mrs.com.br
}

\begin{abstract}
The main objective of this study is to assess the reuse of naturally old ballast that was removed from an operating railroad. In order to verify the viability of its reuse, laboratory tests were carried out, based on the procedures and parameters established in literature. The reuse of ballast would reduce costs, minimize the disposal of this material and reduce quarry extraction. There are several standards regulations the ballast's (gravel) properties, such as size, shape, hardness, abrasion resistance and composition to provide better performance of the rail platform, due to the wide variety of materials and environmental conditions to which they are subjected. Ballast specifications are based on the execution of characterization tests and can be divided according to strength properties and geometric properties. Thus, several specifications have been used by different railway organizations around the world to meet the needs of their projects. One test used to analyze ballast quality is the Los Angeles Abrasion, which provides data on resistance to fragmentation. The durability of the ballast depends on the quality of the gravel related to the original rock composition. This is an important parameter that can be associated with railroad maintenance, which is expensive. A series of tests were carried out to evaluate the ballast properties, as well as an analysis of the geometric and mineralogical characteristics of the gravel, and the impact of the variation of these properties in the performance of the ballast. The viability of reusing the ballast removed from an operating road was then evaluated, and it was concluded that the material is still suitable for reusing, although its properties have undergone a few changes, without modifying its main characteristics and functions.
\end{abstract}

Keywords: Ballast; Reuse; Mineralogical characteristics; Railroad.

\section{Resumo}

O principal objetivo deste estudo foi avaliar o reaproveitamento de um lastro desgastado naturalmente que foi retirado de uma ferrovia em operação. Para verificar a viabilidade de seu reaproveitamento, foram realizados ensaios de laboratório, com base em procedimentos e parâmetros consagrados pela literatura. $\mathrm{O}$ reaproveitamento do lastro reduz custos, minimiza o descarte desse material e reduz a extração da pedreira. Existem várias normas que regulam as propriedades do lastro (brita), como tamanho, forma, dureza, resistência à abrasão e composição que proporcionará melhor desempenho da plataforma ferroviária, devido à grande variedade de materiais e condições ambientais a que estão submetidos. As especificações do lastro são baseadas na execução de ensaios de caracterização e podem ser divididas de acordo com as propriedades de resistência e propriedades geométricas. Assim, diversas especificações têm sido utilizadas por diferentes organizações ferroviárias ao redor do mundo para atender às necessidades de seus projetos. Um ensaio utilizado para analisar a qualidade do lastro é o Abrasão Los Angeles, que fornece dados sobre a resistência à fragmentação. A durabilidade do lastro depende da qualidade da brita utilizada em relação à composição original da rocha. Este é um parâmetro importante que pode ser associado à manutenção da ferrovia, que é onerosa. Uma série de ensaios foi realizada para avaliar as propriedades do lastro, bem como uma análise das características geométricas e mineralógicas da brita, e o impacto da variação dessas propriedades no comportamento do lastro. Foi então avaliada a viabilidade de reaproveitamento do lastro retirado de uma via em operação, concluindo-se que o 
material ainda é adequado para reaproveitamento, embora suas propriedades tenham sofrido algumas alterações, não alteraram suas principais características e funções.

Palavras-chave: Lastro; Reutilização; Características mineralógicas; Ferrovia.

\section{Resumen}

El principal objetivo de este estudio fue evaluar la reutilización de balasto naturalmente desgastado que fue retirado de un ferrocarril en funcionamiento. Para verificar la viabilidad de su reutilización, se realizaron pruebas de laboratorio, con base en los procedimientos y parámetros establecidos en la literatura. La reutilización de lastre reduce costes, minimiza la eliminación de este material y reduce la extracción de canteras. Existen varios estándares que regulan las propiedades del lastre (grava), tales como tamaño, forma, dureza, resistencia a la abrasión y composición que brindarán un mejor desempeño de la plataforma, debido a la amplia variedad de materiales y condiciones ambientales que se encuentran disponibles. Las especificaciones del balasto se basan en la realización de pruebas de caracterización y se pueden dividir según las propiedades de resistencia y las propiedades geométricas. Así, diferentes asociaciones ferroviarias de todo el mundo han utilizado especificaciones diferentes para satisfacer las necesidades de sus proyectos. Una prueba utilizada para analizar la calidad del balasto es Abrasão Los Ángeles, que proporciona datos sobre la resistencia a la fragmentación. La durabilidad del lastre depende de la calidad de la grava utilizada en relación con la composición original de la roca. Este es un parámetro importante que se puede asociar con el mantenimiento del ferrocarril, que es costoso. Se realizaron una serie de ensayos para evaluar las propiedades del balasto, así como un análisis de las características geométricas y mineralógicas de la grava, y el impacto de la variación de propiedades en el comportamiento del balasto. Luego se evaluó la viabilidad de reutilizar el balasto retirado de una vía en operación, concluyendo que el material aún es apto para su reutilización, aunque sus propiedades han sufrido algunos cambios, sus principales características y funciones no han variado.

Palabras clave: Lastre; Reutilizar; Características mineralógicas; Ferrocarril.

\section{Introduction}

In accordance with the Brazilian Association of Technical Standards NBR 5564 (2014), the ballast dimension must be in the range of 12 to $63.5 \mathrm{~mm}$, however, there are several standard regulations that specify these characteristics, such as the Canadian Pacific Railway EN 13450 (2002), AREMA (2012) and also researches carried out by Indraratna, Salim e Rujikiatkamjorn (2011). This parameter does not have a single standard, the same happens with properties related to shape, Los Angeles Abrasion and mineralogical composition, since the ballast specifications are prepared taking into account the diversity of materials and environmental conditions the region of origin of the ballast.

Ballast is formed by granular materials that accommodate the sleepers and its most important functions are: drainage, distribution of loads transmitted to the underlying layers and make resistance to lateral and longitudinal forces. The ballast suffers a reduction in its drainage capacity when the layer reaches a high percentage of clogging, which is due to the presence of particles smaller than 9.5 mm (Sol-Sánchez, Thom, Moreno-Navarro, Rubio-Gamez \& Airey, 2015).

The efficiency of the ballast in performing its functions is verified through its physical state and the characteristics of the grains in relation with size, shape, strength, among others. According to Oda and Iwashita (1999), the behavior of granular materials is verified by the rearrangement and characteristics of the particles. Raymond (1985) emphasized that geometric characteristics, such as shape and texture of aggregates, have great importance for the stability of the railway.

The EN 13450 (2002) evaluates surface texture as the most important factor and considers it as the key parameter for track stability, and ensures that control must be stricter in relation with grain texture than form.

According to Selig and Waters (1994), particle rounding is related to the number of edges, while angularity is the obtaining of these measurements, which is done by means of projecting images of the aggregates.

Jeffs (1989) concluded that ballast angularity is the most important parameter to be analyzed when analyzing plastic deformations, more relevant than other parameters such as durability, maximum diameter and granulometric uniformity. Therefore, the author recommends that the angularity analysis should be included in the evaluation of ballast material and also suggests that a monitoring of the aggregate already applied on the track should be carried out, in order to monitor the process of degradation and rounding caused by train traffic. 
Ballast suffers degradation along its life and this damage should be reduced so the railway is profitable, thus changes in maintenance techniques are needed for a low cost and more efficient way to maintain road geometry.

The research of maintenance techniques aligned with the issue of environmental preservation has gained importance, as environmental standards are increasingly restrictive in the search for methodologies that preserve the environment. One cause of environmental degradation is the inadequate disposal of waste, and one way to avoid this is the reusing of materials, which is also a way of reducing costs (John, 1997).

The objective of this study is to analyze the characteristics of a degraded ballast, removed from a stretch of a railway in operation, and to assess through laboratory tests whether it is still proper for using, and if it meets the geometry and strength specifications to be reused as ballast material. The assessment of the characteristics was carried out through an investigation of the influence of the geometry and mineralogical composition of the gravel, as well as the representativeness of the sample and the adequacy of the results in terms of variation in geometric properties and strength.

\subsection{Degradation of Railway Ballast}

The railway structure is intended to provide an efficient foundation for trains to operate at different speeds and axle loads, as well as stability and safety for users. For that, the road geometry needs be inside the parameters established by the standards, where each component of the structure needs to perform its operational and environmental functions correctly (Indraratna et al., 2011).

When gravel deterioration begins to change the geometric parameters and mechanical behavior of the ballast layer, it becomes necessary to carry out operations to return the geometry of the road, in order to ensure good performance and maintain safety conditions within standards ideals (Sol-Sánchez et al., 2015).

Most ballast specifications prescribe that the gravel layer must contain a low percentage of fines, however, the accumulation of traffic causes the degradation of the material causing fines to occur, changing the rigidity and causing the instability of the railroad. The occurrence of fines in the ballast layer leads to maintenance operations in order to rebuild the geometry of the road, and when the percentage of fines is high, it is necessary to replace all the ballast material (Muniz da Silva, 2002).

The fine material that stiffens the ballast layer comes from the deterioration of the grains due to train traffic, ore spillage, ascent of fine material from the sub-ballast and subgrade, which is called fines pumping. The main cause of ballast breakage is the passage of train traffic, which causes a change in the rigidity of the track since the ballast is an influential component in deformation (Raymond \& Williams, 1978; Selig \& Waters, 1994).

\subsection{Case Study}

The aim of this study is to evaluate the characteristics of a ballast used on a railway in order to obtain information about its properties. The sample of degraded ballast was collected at yard do Arará - RJ (Figure 1 (a) and (b)), during a change operation of the turnout type, which was in service for approximately 15 years. Both the degraded ballast (Figure 2 (a)) and the new ballast (Figure 2(b)) come from the same quarry. Its particle size ranges from $5 \mathrm{~mm}$ to $63.5 \mathrm{~mm}$. 
Figure 1: (a) geographic location of the Japeri quarry - RJ and (b) operation to remove ballast from the Arará yard - RJ.

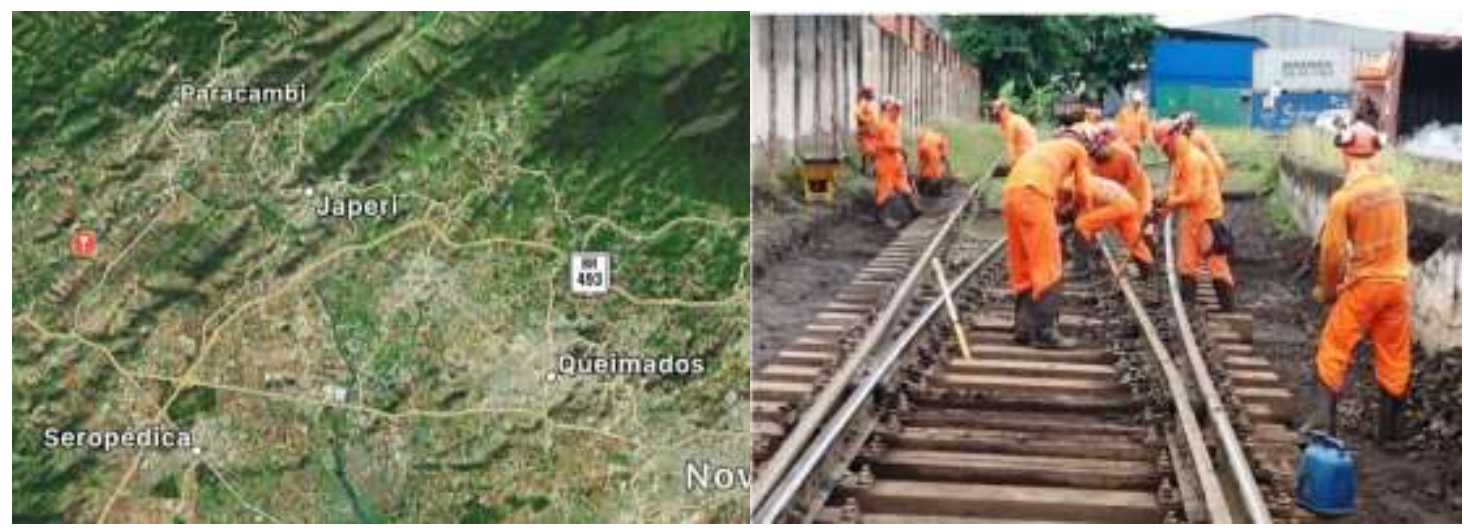

(a)

(b)

Source: MRS (2019).

Figure 2: (a) degraded ballast and (b) new ballast.

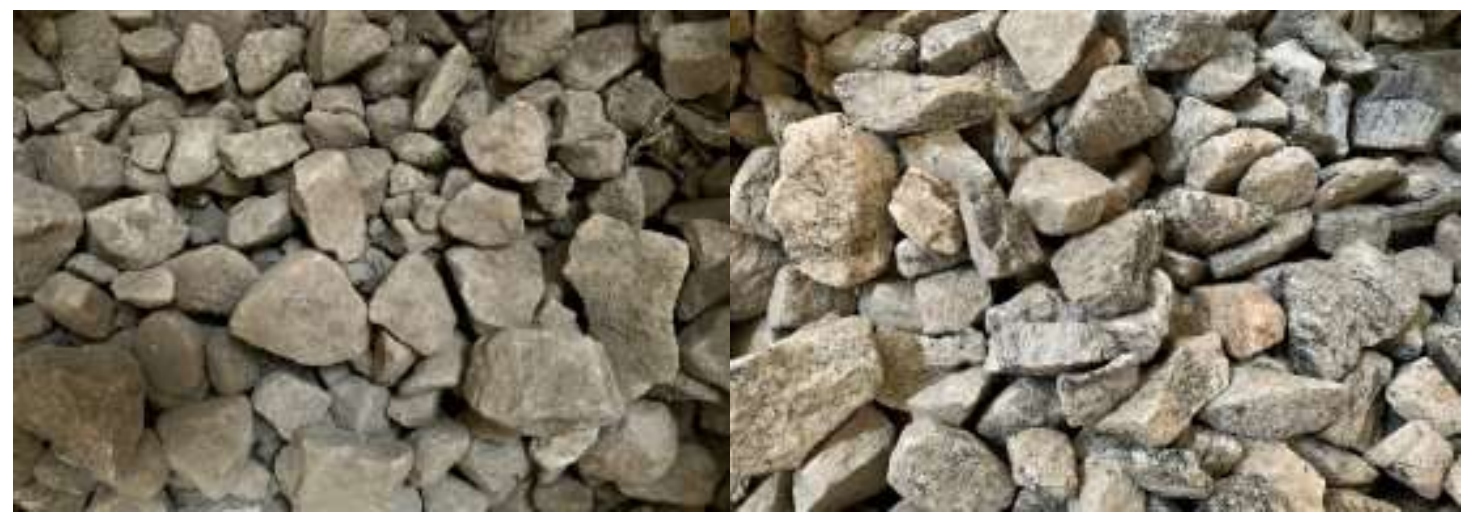

(a)

(b)

Source: Authors.

\section{Methodology}

In order to reduce costs and minimize the inappropriate disposal of waste in the environment, it was necessary to verify the viability of reusing degraded ballast on the railway. Thus, to evaluate ballast reuse, the following tests were carried out on the new and degraded ballast, both from the same quarry: determination of the shape through the maximum and average values of angularity, texture and sphericity; mineralogical composition from X-Ray Diffraction; and Los Angeles Abrasion Test to assess the evolution of ballast's deterioration.

\subsection{Aggregates shape}

According to Jeffs and Tew (1991) the shape of the ballast grains varies due to production process and nature of the deposit of origin. According to the American Railway Engineering Association (1991), 5\% of the composition must be formed by lamellar or elongated particles. However, there is still a lack of definition regarding the admissible percentage of lamellar particles (Jeffs \& Tew, 1991). Raymond (1985) determined that cubic shaped particles are used in high quality ballast, which is also supported by Jeffs and Tew (1991).

Standards ASTM D5821-13 (2017) and ABNT NBR 5564 (2014) indicate the appropriate shape for the aggregate to be used as ballast material. The test is performed by analyzing the amount of fracture on each gravel's face. 
According to Pazos (2015), the experimental procedures used to determine characteristics related to the shape, angularity and surface texture of the aggregates have a certain degree of empiricism, which raises questions about the repeatability of the tests used. To solve this problem, a test developed by Masad and Fletcher (2005) has been used to evaluate the characteristics related to the shape, angularity and surface texture of the aggregates. The test was later improved by Mahmoud, Gates, Masad, Erdoğan, and Garboczi (2010) Mahmoud et al. (2010), resulting in the AIMS (Aggregate Image Measurement System). The maximum dimension of the materials analyzed through digital image processing in AIMS is 25 $\mathrm{mm}$.

Ibiapina (2018) carried out a study on Brazilian aggregates and from data of materials from different regions and proposed a change in the classification limits of materials used in the AIMS, which have North American origins. The limits proposed are shown in Table 1. Figure 3 shows the AIMS equipment and accessories used for image capture and Figure 4 shows the degraded ballast in AIMS tray.

Figure 3: AIMS and equipment details.

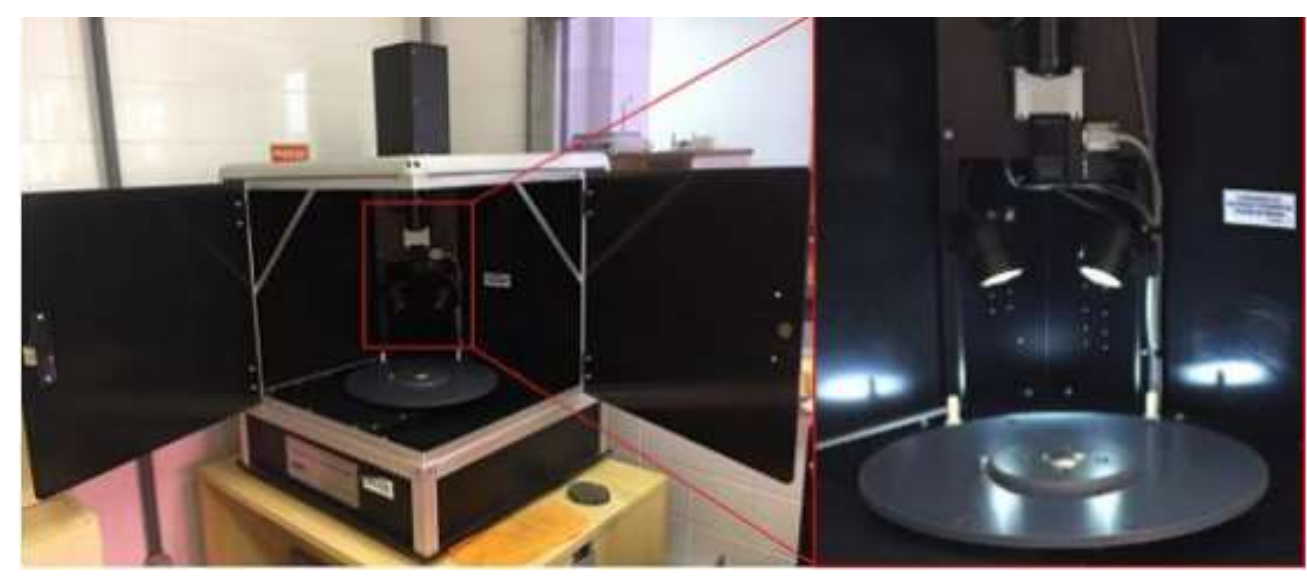

Source: Fengler (2018).

Figure 4: Degraded ballast - AIMS tests.

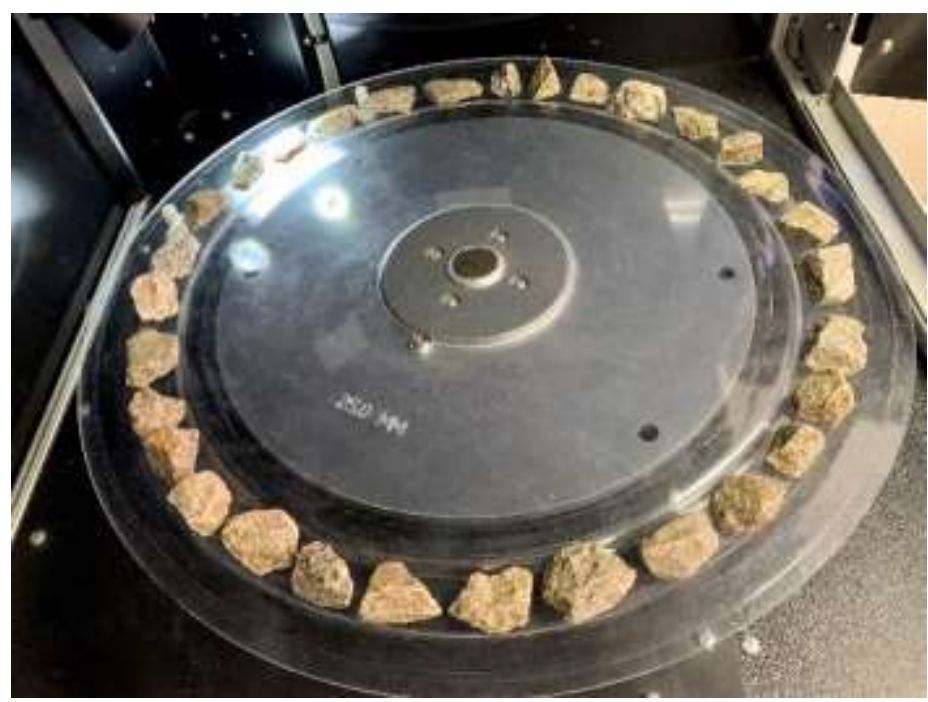

Source: Authors. 
Table 1: AIMS Limits.

\begin{tabular}{l|l|l}
\hline \multicolumn{1}{c}{ Angularity } & \multicolumn{1}{c}{ Limits } \\
\hline Rounded < 1260 & Flat / Elongated <0,5 & \multicolumn{1}{c}{ Texture } \\
\hline Sub-rounded:1260-4080 & Low Sphericity: $0,5-0,7$ & Soft: $260-440$ \\
\hline Subangular: $4080-7180$ & Moderate Sphericity: $0.7-0.9$ & Moderate Roughness: $440-600$ \\
\hline Angular $>7180$ & High Sphericity $>0.9$ & Moderate Roughness: $600-825$ \\
\hline- & - & High Roughness $>825$ \\
\hline
\end{tabular}

Source: Adapted from Ibiapina (2018).

\subsection{Los Angeles Abrasion Test}

The abrasion test follows ABNT NBR NM 51 (2001), ASTM C131 (2006) and ASTM C535 (2016) standards. The procedure is to evaluate the reduction in the mass of aggregates that have suffered collisions, in relation to their initial mass when placed inside a metallic cylinder with a horizontal axis. Cast iron spheres are placed together with the ballast, the objects are subjected to rotations at a speed of 30 to 33rpm (Selig \& Waters, 1994). The results obtained through this index help to determine the useful life of the ballast layer.

To determine the wear by abrasion, Equation 01 is applied, which evaluates the reduction in the mass of aggregates that suffered collisions in relation to their initial mass.

$$
L A=\frac{m_{j}-m_{f}}{m_{j}} \times 100
$$

Where:

LA: Los Angeles abrasion wear of given diameter range of gravel, \%;

$m_{j}$ : initial sample mass (dry), g;

$m_{f}$ : mass of material retained in sieve $1.7 \mathrm{~mm}$ after abrasion, $\mathrm{g}$.

\subsection{X-Ray Diffraction}

The strength of the parent rock is a characteristic that must be taken into account when analyzing ballast degradation, settlement and lateral deformation of the railway. The tensile and compression strength of ballast comes from the rock from which it originated. When the material is exposed to loading, the more fragile particles suffer more degradation than the more resistant particles. Despite such conclusions, the strength of the parent rock is not a criterion used in the specification of ballast material, its strength is implied in the selection of the material, which includes the Los Angeles Abrasion test and in some cases the petrographic or the X-Ray Diffraction test, which are two techniques used to determine the mineralogical composition of materials, whose results help to estimate the useful life of the ballast (Vizcarra, 2015). In accordance with Watters, Klassen and Clifton (1987), one way to facilitate the process of identifying the causes that lead to ballast deterioration is the specification of the rock used.

For the analysis of X-Ray Diffraction after the crushing process, the material is quartered, ground and homogenized (Silva, 2013). The X-Ray Diffraction test with powder material is the best technique available for the identification and quantification of minerals present in rocks (Środoń, Drits, McCarty, Hsieh, \& Eberl, (2001), which is an important tool in the qualification of ballast, as it presents more conclusive results than those provided by other tests (Raymond \& Diyaljee, 1979). 
The effects of abrasion are less observed in rocks composed of harder minerals, thus the hardness from the Mohs scale and the mineral elements existing in the rock should be analyzed together (Raymond, 1979). According to this methodology the percentage of mineral needs to be estimated at 5.5 or more from X-Ray Diffraction, which provides the mineralogical composition of each mineral present in the sample. The result varies depending on the Los Angeles Abrasion Index (LAA) and the percentage by volume of minerals with Mohs hardness equal to or greater than 5.5. Raymond (1979) proposed the classification in Table 2, which determines the classes of ballast ranging from 1 to 6, where the smaller the class number, the better the quality of the ballast.

Table 2: Ballast classification according to Mohs hardness and LAA.

\begin{tabular}{c|c|c|c|c}
\hline \multirow{2}{*}{ LAA } & \multicolumn{5}{|c}{ Percentage by volume of minerals with } \\
\cline { 2 - 5 } & $0-25$ & $25-50$ & $50-75$ & $75-100$ \\
\hline $0-10$ & 3 & 3 & 2 & 1 \\
\hline $10 / 15$ & 3 & 3 & 2 & 1 \\
\hline $15-20$ & 4 & 4 & 2 & 2 \\
\hline $20-25$ & 4 & 4 & 3 & 2 \\
\hline $25-30$ & 5 & 4 & 3 & 2 \\
\hline $30-35$ & 5 & 5 & 3 & 3 \\
\hline $35-40$ & 5 & 5 & 4 & 3 \\
\hline $40-50$ & 6 & 5 & 4 & 4 \\
\hline
\end{tabular}

Source: Raymond (1979).

\section{Results}

\subsection{Shape}

The shape of the aggregates was obtained using AIMS equipment. The test was performed both on new ballast and on degraded ballast. The sample of each material consisted of 50 particles of the fractions retained in each of the sieves: $9.5 \mathrm{~mm}$, $12.5 \mathrm{~mm}, 19 \mathrm{~mm}$ and $25.4 \mathrm{~mm}$ (Figure 5). 
Figure 5: New (a) and degraded (b) ballast separated by particle size for testing.

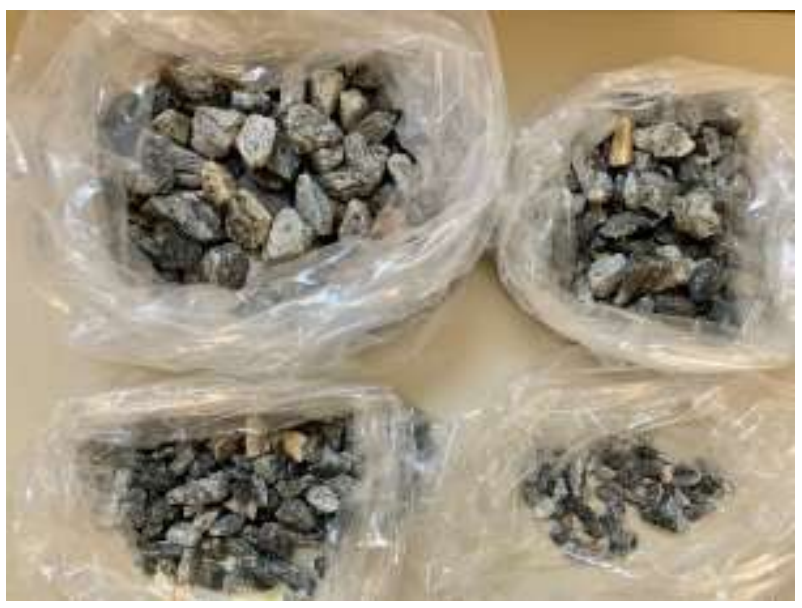

(a)

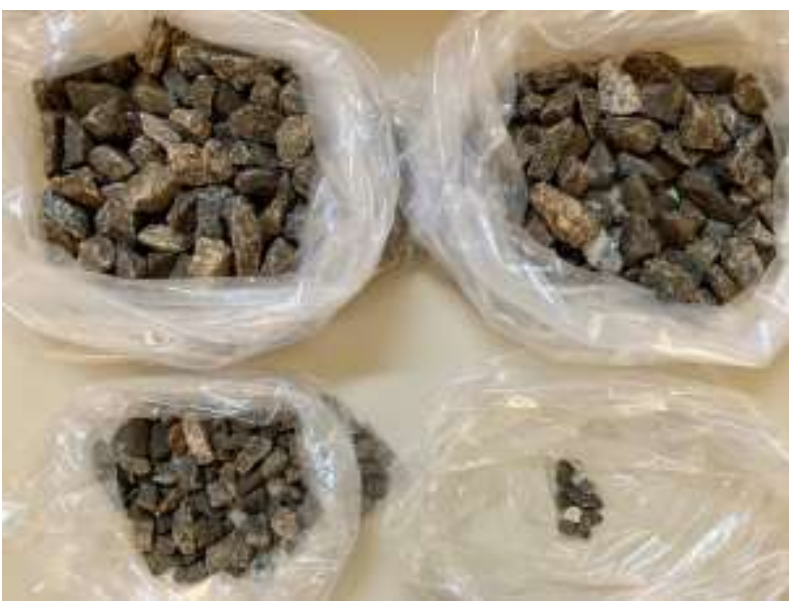

(b)

Source: Authors.

The test was carried out to compare the average and maximum values of angularity, texture and sphericity obtained through the tested aggregates. The first analysis performed was the angularity. The results found for the distribution of maximum and average angularity of new ballast and degraded ballast are shown in Figure 6.

In the new ballast, there was a tendency to decrease angularity as the aggregate size increased, a phenomenon observed in the distribution of maximum and average angularity, this fact may be related to the crusher used or even the transport that can cause wear of the material if it comes from a less resistant rock.

Degraded ballast did not follow the same trend, the maximum angularity increased in the three largest aggregate sizes, but in the $9.5 \mathrm{~mm}$ fraction it decreased. Considering the average values of angularity, the degraded material also suffered a decrease in angularity as the size of the aggregate increased in the three smallest aggregate sizes, however, in the fraction of 25 $\mathrm{mm}$ the angularity increased. This could be explained by the wear suffered on the railroad. In accordance with the limits proposed by Ibiapina (2018) in relation to angularity, degraded and new ballast were under-rounded.

Figure 6: Maximum and average angularity values.

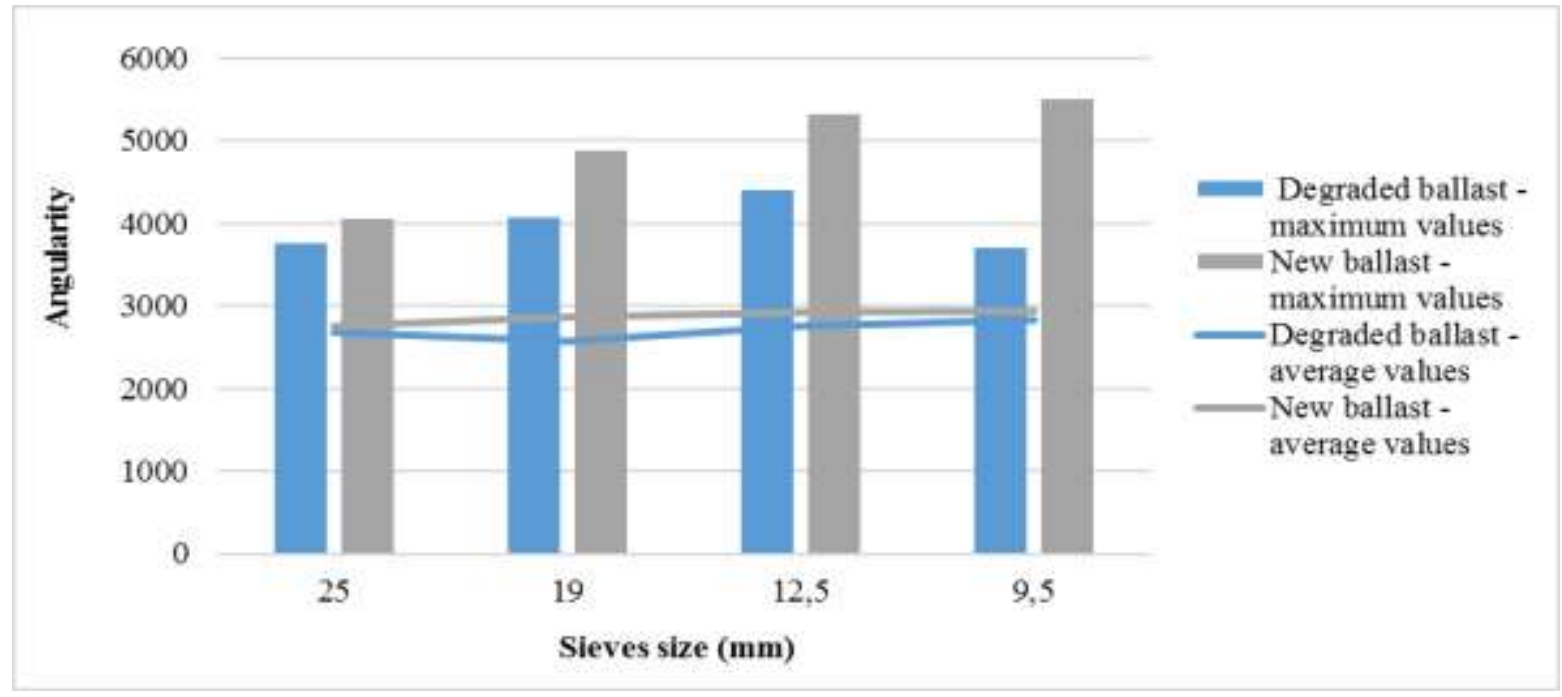

Source: Authors.

Figure 7 shows the results of the maximum and mean distribution of materials texture. The maximum texture 
variation of the aggregates does not follow a trend, however, when evaluating the average distribution, it is observed that the degraded ballast had higher values, probably related to the presence of smaller grains compared to the new ballast. According to the limits assigned by Ibiapina (2018) in relation to texture, the two ballast materials showed low roughness.

Figure 8 shows the distribution of the maximum and average sphericity of the aggregates. The degraded ballast has higher values of maximum and average sphericity, which can be explained by the fact that the material has already been exposed to traffic. Analyzing the mean sphericity obtained, and the limits imposed by Ibiapina (2018), the new and degraded ballast presented moderate to low sphericity.

Figure 7: Maximum and average texture values.

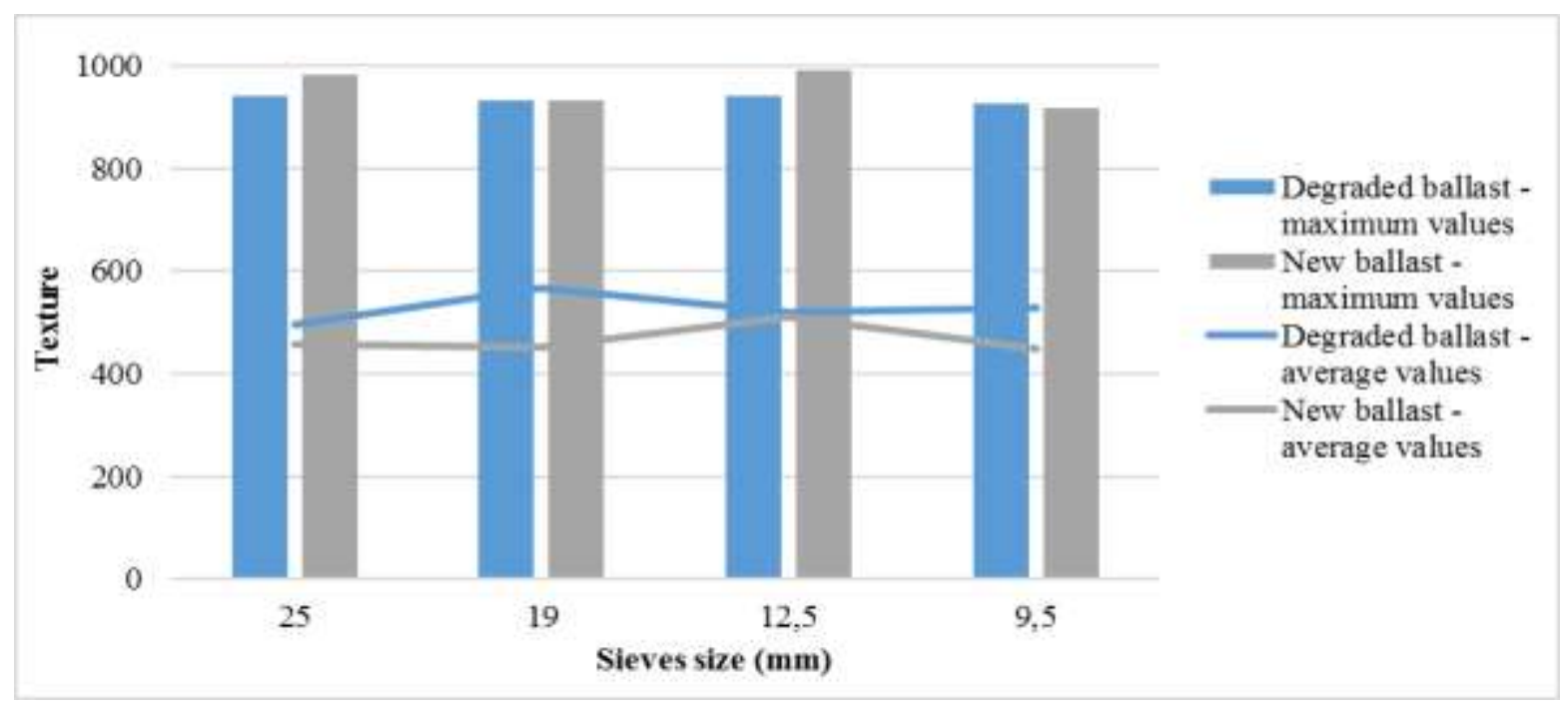

Source: Authors.

Figure 8: Maximum and average sphericity values.

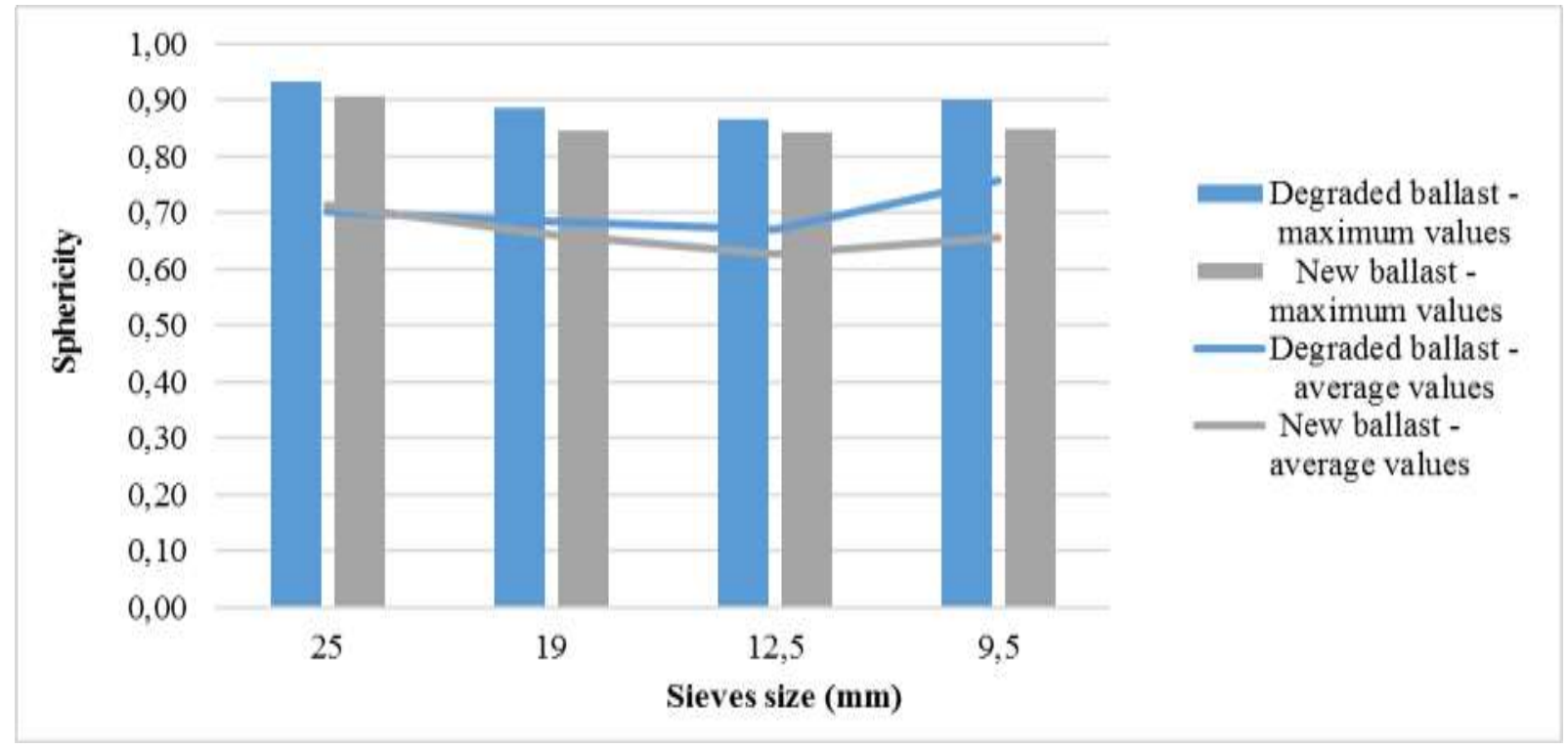

Source: Authors. 


\subsection{Los Angeles Abrasion}

The maximum Los Angeles Abrasion value allowed for using rail ballast is 30\% according to ABNT NBR 5564 (2014) and DNIT ETM-002 (2016). According to AREMA (2012), the material has to fit in the range of $25 \%$ to $40 \%$ and according to VALEC (2012) the limit is set at $40 \%$ maximum. The abrasion value of the new ballast was $36 \%$, which is high, but it is still within the standards established by AREMA (2012) and VALEC (2012). Degraded ballast, on the other hand, presented greater resistance to fragmentation, with an abrasion value of $31.4 \%$, since it was already submitted to stress in the field.

\subsection{X-Ray Diffraction}

The characterization of the sample is conducted through comparison between the diffractogram of the tested sample with reference standards, available in DRX databases. In this procedure, the most intense peaks of each crystalline compound present in the database are compared to the peaks of the sample diffractogram. Once the search and comparison process is finished, the values of the search results are displayed. The coincidence of values, or near coincidence, leads to identification the mineral (Kahn, 1988; Silva, 2013). Figures 9 and 10 illustrate the likely substances present in the new and degraded ballast samples. The characterizations of the samples were performed using the Panalytical High Score Plus software, by comparing the generated diffractograms with reference standards available in the ICDD PDF2 database.

Figure 9: Possible substances in the new ballast.

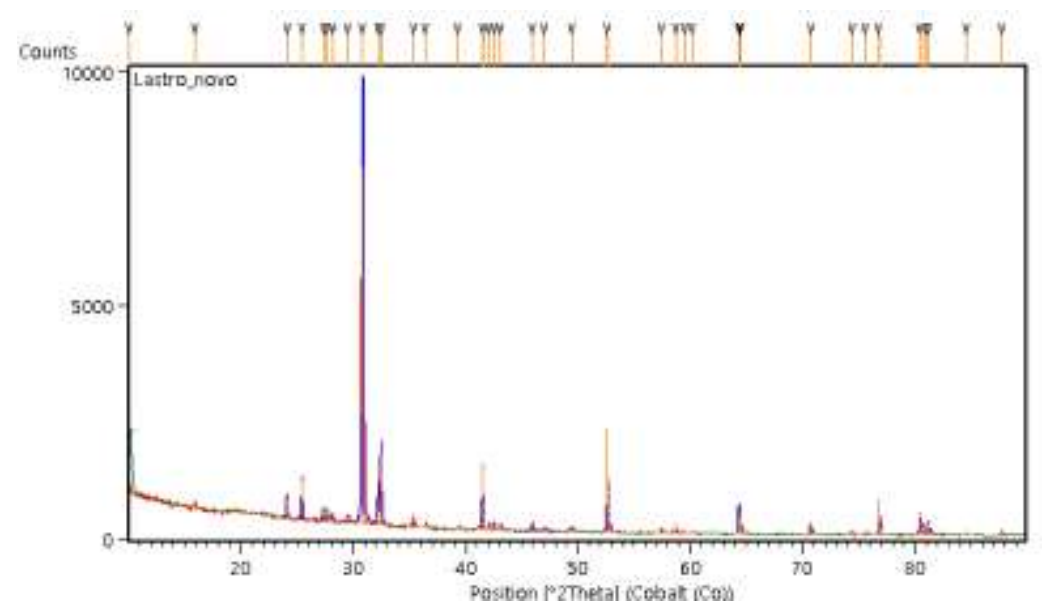

\begin{tabular}{|c|c|c|c|}
\hline \multicolumn{4}{|c|}{ Candidates: } \\
\hline No. & Ref. Code & C Score & Compound Name \\
\hline \multicolumn{2}{|r|}{1 Ic00 $00-008-0415$} & 35 & Carbon \\
\hline \multicolumn{2}{|r|}{2 IG00 $00-012-0212$} & 35 & Carbon \\
\hline \multicolumn{2}{|r|}{3 1000 01-089-8936 } & 33 & Silicon Oxide \\
\hline \multicolumn{2}{|r|}{4 Iட@D $00-041-1487$} & 30 & Carbon \\
\hline \multicolumn{2}{|r|}{5 1000 01-089-8937 } & 30 & Silicon Oxide \\
\hline \multicolumn{2}{|r|}{$6100001-089-8938$} & 29 & Silicon Oxide \\
\hline \multicolumn{2}{|r|}{7 Icon $00-042-1342$} & 29 & Cadmium Carbonate \\
\hline \multicolumn{2}{|r|}{8 1600 $00-003-0499$} & 28 & Sodium Calcium Alumin \\
\hline \multicolumn{2}{|r|}{9 Ic00 $00-0441433$} & 27 & Cobalt Iron \\
\hline \multicolumn{2}{|r|}{10 1600 01-076-0938 } & 26 & Silicon Oxide \\
\hline \multicolumn{2}{|r|}{11 1600 01-076-0898 } & 26 & Sodium Aluminum Silice \\
\hline \multicolumn{2}{|r|}{12 I000 01-076-0939 } & 26 & Silicon Oxide \\
\hline \multicolumn{2}{|r|}{13 1600 01-076-0941 } & 26 & Silicon Oxide \\
\hline \multicolumn{2}{|r|}{14 Ic00 01-089-7213 } & 25 & Carbon \\
\hline
\end{tabular}

Source: Authors.

Figure 11 and Figure 12 shows the candidate minerals for characterization of the samples of degraded ballast and new ballast respectively. Each crystallographic number refers to a mineral, and in the degraded ballast the minerals were: Silicon Dioxide, Quartz, with 0.3\%; Copper Iodide, Marshite, 0.1\%; Sodium Aluminosilicate, Albite, with $14.9 \%$ and Beryllium-Zinc Silicate Sulfite, Genthelvita, with 84.7\%. In the new ballast, the minerals were: Quartz, Silicon Oxide with 0.5\%; Labradorite, Sodium Calcium Aluminum Silicate with 4\%; Cobalt with 58.4\% and Langita with 9.2\%.

Thus, through the correlation proposed by Raymond (1979), the degraded ballast had 99.9\% of minerals with Mohs hardness greater than 5.5, while the new ballast had $90.8 \%$ of minerals with Mohs hardness greater than 5.5 . For LAA in the range of $30-40 \%$ and with $75-100 \%$ of volume with Mohs hardness $\geq 5.5$, both ballasts are classified as class 3 . 
Figure 10: Possible substances in the degraded ballast.
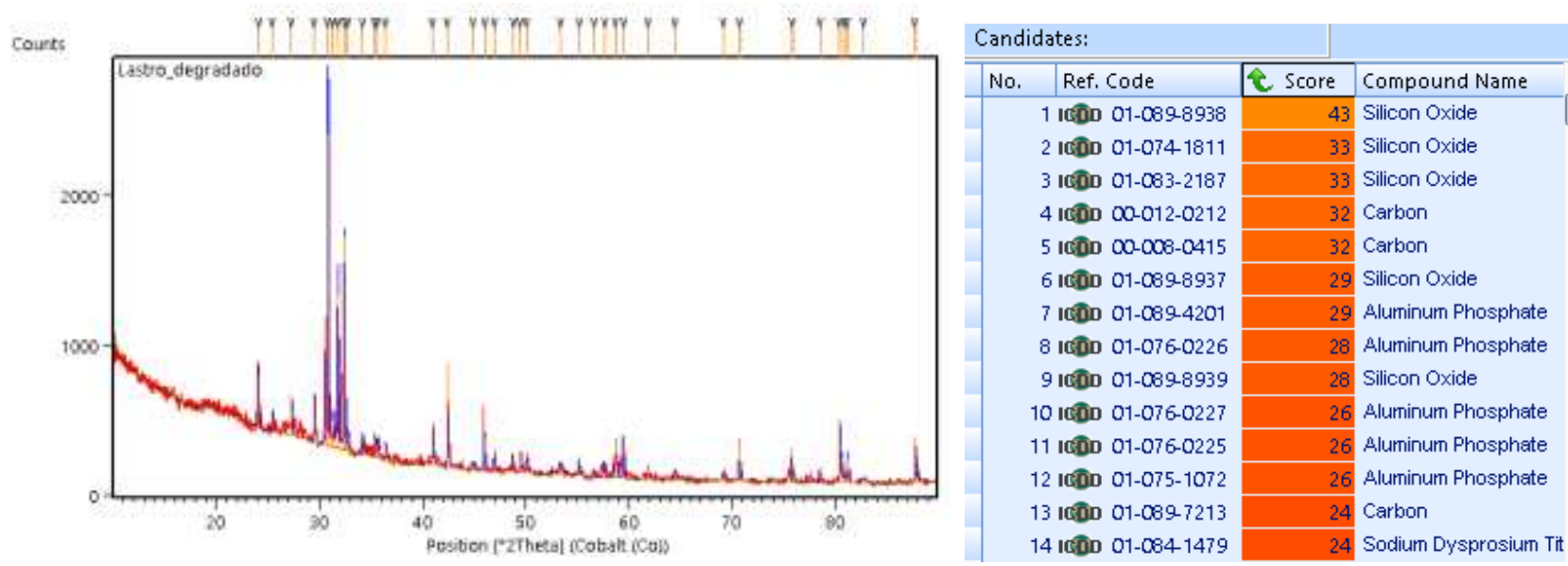

Source: Authors.

Figure 11: Minerals present on degraded ballast.

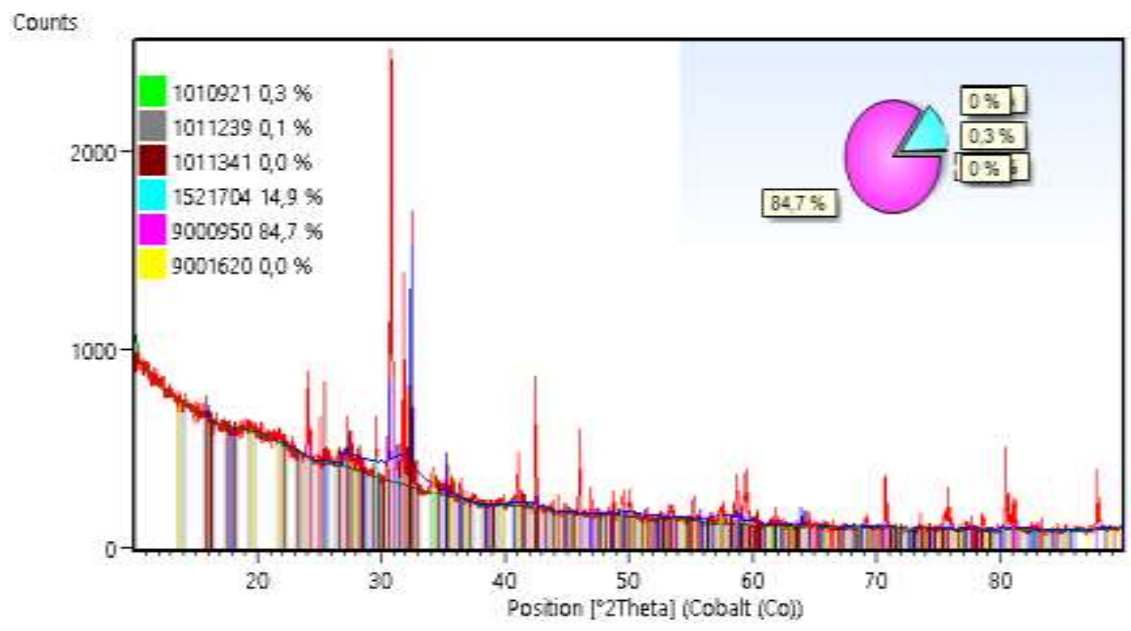

Source: Authors.

Figure 12: Minerals present on new ballast.

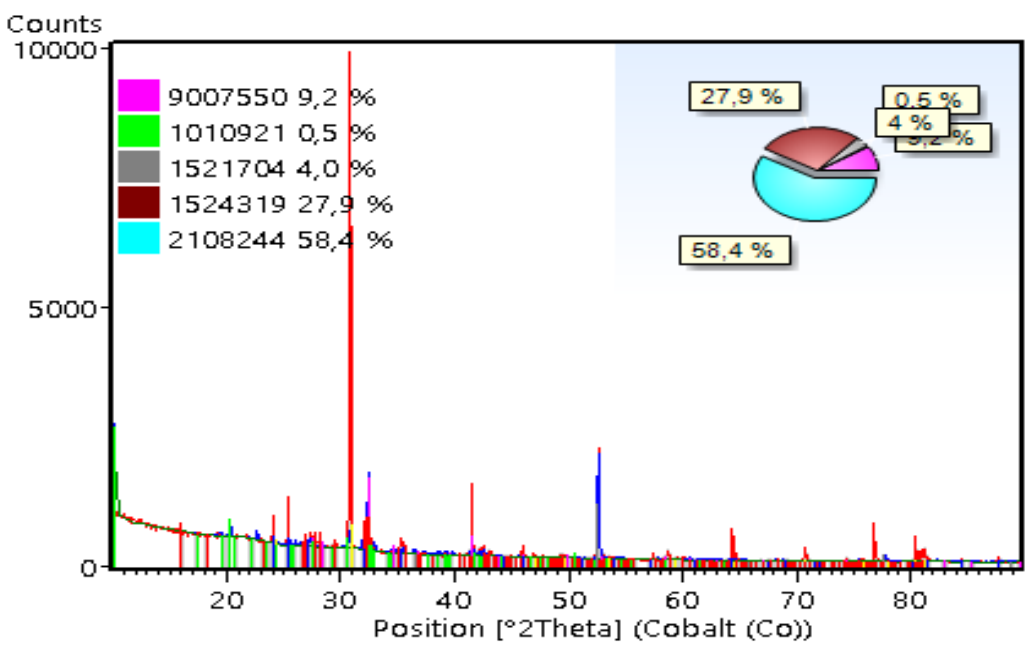

Source: Authors. 


\section{Discussion}

The value obtained in Los Angeles Abrasion Test of the new material was $36 \%$ and the degraded ballast $31.5 \%$, this was due to the fact that the degraded material had already been exposed to stresses on the road, thus the lamellar and elongated particles (more prone to breakage) were already reduced in size, thus the cubic-shaped particles (more resistant to breakage) were predominant, so when this material was exposed to abrasion it suffered less fragmentation effects than new ballast, which had never been submitted to stress. This behavior was already observed by Raymond (1985), who states that the cubic-shaped particles are used in high quality ballast.

The angularity, texture and sphericity values of the new and degraded ballast fit into the same intervals according to Ibiapina (2018), however, comparing the results with each other, the main conclusions are:

- Jeffs (1989) proposed that the angularity of the ballast is the most important parameter in the control of plastic deformations, and through the result of the angularity it was possible to observe that both the new and the degraded ballast suffered a reduction in angularity as the size of the aggregate increased, however, the degraded ballast presented smaller particle sizes in relation to the new ballast, and with this it is concluded that the angularity was higher in the degraded material.

- Through the tests it was observed that the degraded ballast had higher texture values, and according to the Canadian Pacific Railway (2002), texture is the key parameter for the stability of the road.

- Through the X-Ray Diffraction test it was possible to quantify the minerals present in the two materials under study, and through the correlation proposed by Raymond (1979) it was observed that the two materials presented the index 3 , proving that the degraded ballast is still fit for reuse.

It is common knowledge in ballast material specifications that the gravel layer must contain a low percentage of fines, however the increase in loading cycles leads to deterioration of the grains causing the appearance of fines in the layer, making maintenance necessary. However, through this study it was observed that the material under charge for 15 years is still suitable for reuse, considering the characterization and mineralogical tests. Thus, it is not necessary to replace the material, it is only necessary to carry out an evaluation in order to discard the fines that impair drainage and can cause other damage to the behavior of the layer.

\section{Final Considerations}

In this work, the viability of reusing ballast removed from an operating road was evaluated, and it was concluded that the degraded material is still suitable for use, as its properties have been maintained and are still in accordance with the criteria required by the ballast material specifications.

One criterion to be evaluated is the graduation of the ballast, and particles smaller than $9.5 \mathrm{~mm}$ can cause loss of drainage efficiency and cause the layer to clog (Indraratna et al., 2011), however, by removing the fine material the ballast can be reused.

In the present study, the geometric and strength characteristics were evaluated through the Los Angeles abrasion test, a suggestion for future work (which is already in progress) is to carry out a study of the material's mechanical properties through resilient modulus (MR) tests and permanent deformation (DP), in order to assess the degradation suffered by the ballast with an increase in the number of loading cycles.

\section{Acknowledgments}

To CAPES for its support in the form of the first author's master's scholarship and to the company MRS Logistic S.A. 
for the partnership in the research project.

\section{References}

Associação Brasileira de Normas Técnicas. ABNT NM 51 (2001). Agregado graúdo - Ensaio de abrasão Los Angeles.

Associação Brasileira de Normas Técnicas. ABNT NBR 5564 (2014). Via férrea-Lastro ferroviário - Requisitos e métodos de ensaio.

American Railway Engineering and Maintenance of Way Association AREMA (2012). Manual for Railway Engineering. Vol. II, Lanham, Maryland, USA.

American Society for Testing and Materials. ASTM C131 (2006). Standard test method for resistance to degradation of small-size coarse aggregate by abrasion and impact in the Los Angeles machine: West Conshohocken, PA, USA.

American Society for Testing and Materials. ASTM C535 (2016). Standard Test Method for Resistance to Degradation of Large-Size Coarse Aggregate by Abrasion and Impact in the Los Angeles Machine: West Conshohocken, PA, USA.

American Society for Testing and Materials. ASTM D5821-13 (2017). Standard Test Method for Determining the Percentage of Fractured Particles in Coarse Aggregate: West Conshohocken, PA, USA.

Kahn, H. (1988). Caracterização mineralógica e tecnológica da jazida de fosfato do maciço alcalino de Anitápolis, SC. Tese de Doutorado. Universidade de São Paulo. 10.11606/D.44.1988.tde-11092015-110420.

Canadian Pacific Railway. EN-13450 (2002). Arids for railroad ballast. European Standard. Home page. pp. 1-38.

Departamento Nacional de Infraestrutura de Transportes. DNIT ETM-002 (2016). Especificação Técnica de Material ETM - 002: Lastro Padrão de Brita. Brasil.

Fengler, R. Z. (2018). Caracterização de ligantes e misturas asfálticas modificados com a adição de Trinidad lake asphalt. Dissertação de Mestrado em Engenharia Civil. COPPE/UFRJ.

Ibiapina, D. S. (2018). Proposição de um sistema de classificação das propriedades de forma de agregados caracterizados com o uso do processamento digital de imagens para a seleção de materiais brasileiros. Tese de Doutorado em Engenharia de Transportes. Centro de Tecnologia, Universidade Federal do Ceará, Fortaleza. Obtido de http://www.repositorio.ufc.br/handle/riufc/34019.

Indraratna, B., Salim, W., \& Rujikiatkamjorn, C. (2011). Advanced Rail Geotechnology - Ballasted Track CRC Press, London. Retrieved from https://doi.org/10.1201/b10861.

Jeffs, T. (1989). Towards ballast life cycle costing. In Fourth International Heavy Haul Railway Conference 1989: Railways in Action; Preprints of Papers. Institution of Engineers, Australia. Retrieved from https://search.informit.org/doi/abs/10.3316/informit.637507885841220.

Jeffs, T., \& Tew, G. P. (1991). A review of track design procedures: sleepers and ballast, Vol. 2. Railways of Australia BHP Research, Melbourne Laboratories, Melbourne, Australia.

John, V. M. (1997). Pesquisa e desenvolvimento de mercado para resíduos. In Workshop sobre reciclagem e reutilização de resíduos como materiais de construção civil, São Paulo: EPUSP/ANTAC. 170p, (pp. 21-30).

Mahmoud, E., Gates, L., Masad, E., Erdoğan, S., \& Garboczi, E. (2010). Comprehensive evaluation of AIMS texture, angularity, and dimension measurements. Journal of Materials in Civil Engineering, 22(4), 369-379. Retrieved from https://ascelibrary.org/doi/full/10.1061/\%28ASCE\%29MT.19435533.0000033 .

MRS. (2019). Trabalho bem-sucedido: equipes MRS desenvolvem solução para facilitar manobras com diversas combinações de vagões no pátio do Arará. MRS Logística. Obtido de https://www.mrs.com.br/post-newsletter/trabalho-bem-sucedido-equipes-mrs-desenvolvem-solucao-para-facilitar-manobras-comdiversas-combinacoes-de-vagoes-no-patio-do-arara/.

Masad, E., \& Fletcher, T. (2005). Aggregate imaging system (AIMS): Basics and applications (No. FHAWA/TX-05/5-1707-01-1). Texas Transportation Institute, Texas A \& M University System. Retrieved from https://static.tti.tamu.edu/tti.tamu.edu/documents/5-1707-01-1.pdf.

Muniz da Silva, L. F. (2002). Fundamentos para um sistema de gerência de manutenção de pavimentos ferroviários utilizando critério de deformação resiliente. Tese de Doutorado em Engenharia Civil, COPPE/UFRJ, RJ. Obtido de http://www.munizspada.com.br/pdfs/tese_muniz.pdf.

Oda, M \& Iwashita, K (1999). An introduction mechanics of granular materials. 1, 1-5. Elsevier, Amsterdam.

Pazos, A. G. (2015). Efeito de propriedades morfológicas de agregados no comportamento mecânico de misturas asfálticas. Dissertação de Mestrado. Universidade Federal do Rio de Janeiro. http://www.coc.ufrj.br/index.php?option=com_content\&view=article\&id=4540:abraham-guerreropazos\&catid=388\&Itemid=153\&lang=pt-br.

Raymond, G. P. (1979). Railroad Ballast Prescription: State-of-the-Art. Journal of the Geotechnical Engineering Division, ASCE, 105, pp. 305-322.a66J. Geotech. Engrg. Div. https://ascelibrary.org/doi/abs/10.1061/AJGEB6.0000772.

Raymond, G. P., \& Diyaljee, V. A. (1979). Railroad Ballast Ranking Classification. Journal of Geotechnical Engineering Division, ASCE, 105 , pp. $133-1153$.

Raymond, G. P. (1985). Analysis of track support and determination of track modulus. Transportation Research Record, 1022, 80-90. Retrieved from https://onlinepubs.trb.org/Onlinepubs/trr/1985/1022/1022-011.pdf. 
Research, Society and Development, v. 10, n. 13, e277101321231, 2021

(CC BY 4.0) | ISSN 2525-3409 | DOI: http://dx.doi.org/10.33448/rsd-v10i13.21231

Raymond, G. P., \& Williams, D. R. (1978). Repeated load triaxial tests on a dolomite ballast. Journal of the Geotechnical Engineering Division, 104(7), 10131029. https://ascelibrary.org/doi/abs/10.1061/AJGEB6.0000655.

Selig, E. T., \& Waters, J. M. (1994). Track geotechnology and substructure management. Thomas Telford Services Ltd.

Silva, A. L. (2013). Caracterização mineralógica por difração de raios X e determinação de terras raras por ICP-MS de rochas da região sul da Bahia. Dissertação de Mestrado em Ciências e Técnicas Nucleares. Universidade Federal de Minas Gerais. https://repositorio.ufmg.br/handle/1843/BUBD-97XP2T.

Sol-Sánchez, M., Thom, N. H., Moreno-Navarro, F., Rubio-Gamez, M. C., \& Airey, G. D. (2015). A study into the use of crumb rubber in railway ballast. Construction and Building Materials, 75, 19-24. https://www.sciencedirect.com/science/article/pii/S0950061814011970?via\%3Dihub.

Środoń, J., Drits, V. A., McCarty, D. K., Hsieh, J. C., \& Eberl, D. D. (2001). Quantitative X-ray diffraction analysis of clay-bearing rocks from random preparations. Clays and Clay Minerals, 49(6), 514-528. https://link.springer.com/article/10.1346/CCMN.2001.0490604.

VALEC 80-EM-033A-58-8006 (2012). Pedra britada para lastro. VALEC Engenharia, Construção e Ferrovias S.A. Brasília, DF, Brasil.

Vizcarra, G. O. C. (2015). Efeito da granulometria no comportamento mecânico de lastro ferroviário. Tese de Doutorado em Engenharia Civil. Pontifícia Universidade Católica do Rio de Janeiro. https://www2.dbd.puc-rio.br/pergamum/tesesabertas/1012316_2015_pretextual.pdf

Watters, B. R., Klassen, M. J., \& Clifton, A. W. (1987). Evaluation of ballast materials using petrographic criteria. Transportation Research Record, Washington, 1131, 45-63. https://trid.trb.org/view/282807.

X'PERT High Score Plus Software (2012). Version 2.2a. Release 1-Sep-2012. PANalytical (Licensed modules PW3212). 1 CD-RO. 